\title{
An Overview on Explicit and Implicit instructions on Learners' Pragmatic Awareness in Making Request in English
}

\author{
Saeedeh Shokouhi \\ English Language Teacher, Abhar, Zanjan, Iran \\ E-mail: Shokouhi.Saeede@gmail.com
}

Received: April 3, 2016 Accepted: April 28, 2016 Published: May 2, 2016

doi:10.5296/jsel.v4i1.9408 URL: http://dx.doi.org/10.5296/jsel.v4i1.9408

\begin{abstract}
One of the important part of the pragmatics studies in recent years is about the intercultural communication. EFL learners should know both grammatical competence and also sociolinguistic rules to use the language in an appropriate context. This review explores the effect of the explicit and implicit instruction on the learners' attention in the production of the speech act of request. Pragmatics includes "the study of how speakers use and understand speech acts" (Richards and Schmidt 2002). Moreover, pragmatics plays a very important role in the production and perception of the language. That is why interlocutors should have enough pragmatic knowledge to produce and perceive the proper and intended speech acts based on context. Therefore, having pragmatic competence is one of the key factors in the process of communication. Pragmatic competence in foreign language contexts is defined as the knowledge of communicative action or speech acts, how to perform it, and the ability to utilize the language in proper ways based on the context or contextual factors (Kasper 1997; Kasper \& Roever 2005).
\end{abstract}

Keywords: explicit instruction, implicit instruction, pragmatic competence, request, speech act 


\section{Introduction}

Most of the studies focus on second language grammatical development and little attention to the L2 learners' development of pragmatic competence. Pragmatics deals with the particular aspect of the individuals' communication, namely the interaction between the language and the context in which it is used (Chopman, 2011, p. 10). Pragmatic competence is defined by Barron (2003) as "knowledge of the linguistic resources available in a given language for realizing particular illocutions knowledge of the sequential aspects of speech acts and finally, knowledge of the appropriate contextual use of the particular languages' linguistic resources."

Many researchers who use the term pragmatics rely on Crystal's (1997) definition, which defines pragmatics as "the study of language from the point of view of users, especially of the choices they make, the constraints they encounter in using language in social interaction and the effects their use of language has on other participants in the act of communication" ( $p$. 301). Research about the performance of speech acts by EFL learners have offered various explanations for the differences between learners' and native speakers' (NSs) realizations (Bardovi- Harlig, 2001). However, studies on the role of instruction of politeness strategies for speech act realization in helping students achieve pragmatic appropriateness in their speech are still limited. Lack of pragmatic awareness is most evident among EFL learners while communicating with people from other cultures. Teachers in EFL classrooms are partly responsible for the lack of pragmatic knowledge among learners. EFL teachers mostly concentrate on the grammar and vocabulary (linguistic competence) and they do not pay sufficient attention to the pragmatic or sociolinguistic dimension of language. Therefore, EFL learners may produce utterances that are perfectly grammatical, but they may violate social norms of the target language because they lack pragmatic competence (appropriateness of meaning) to support grammatical competence (appropriateness of form) (Thomas 1983; Leech 1983; Bardovi-Harlig \& Dornyei 1998).

Eslami-Rasekh, Eslami-Rasekh and Fatahi (2004) also emphasize this issue and caution that the communication of EFL learners with native speakers (NSs) may bring about pragmatic failure due to the lack of pragmatic knowledge of the sociocultural norms of the target community. As such, pragmatic competence should be acquired in order to lessen pragmatic failure or communication breakdowns between NSs and NNSs. Elsami (2005) states that learners should be able to use the language efficiently to perceive the language in context (contextualized language). Iranian EFL students are not exposed to the target community and culture and they find it extremely difficult to produce or sometimes understand a speech act. Moreover, they often fail to identify the proper function of speech acts in EFL educational settings (Eslami-rasekh and Mardani 2010).A key facet of pragmatic competence is to understand the speech acts and their appropriateness in a specific context (Cheng 2005, p. 9). Speech acts, in its general sense, have been defined as the utterances and the total situation in which the utterances are issued (Austin 1962).In current review two kinds of instructions, namely, implicit and explicit instructions are compared.

\subsection{Interlanguage Pragmatics}

Interlanguage pragmatics is defined as the study of the learners use and acquisition of 
linguistic patterns in a second language (Kasper, 1999; Rose, 2000). Rose (2000) mentions that there have been many cross_ sectional studies (e.g., Seigal, 1994, 1996; Ellis, 1992; Bardovi_Harlig \& Hartford, 1993) and only a few longitudinal studies done related to the effect of the instructions on pragmatic development over a period of the time (Bouton, 1994; Billmayer, 1990; House, 1996). Schmidt (1993) for example has identified the role of "conscious awareness" in the acquisition of the pragmatic competence. He concludes that attention to pragmatic competence is a necessary condition for acquiring it.

\subsection{Politeness}

The earliest contributions to the development of politeness theory came from Robin Lakoff who published two articles on the subject in the early 1970 s. Lakoff's more general motivation was to discuss that the formal rules of semantic and syntax of a language, could never do the full job of explaining the differences in acceptability and interpretation between different utterances. For this, extra linguistic contextual factors are important: respective status of speaker and addressee, the type of social situation in which they found themselves, the real _ world knowledge or beliefs a producer brings to discourse.

Lakoff suggests two basic rules of pragmatic competence, namely "Be clear" and "be polite" (lakoff 1973: 296).Depending on the nature of the context one or other of these rules will win or will overrule the other. In very formal or technical contexts the correct conveying of information is prized highly, so in the courtroom or lecture room for example, clarity is overruled than politeness. But in many every day conversations in different social settings, the establishing social relationship is more important. So in the most of the cases of language use, the politeness is more important than clarity.

\section{Speech Acts}

Speech acts are utterances that serve a particular function in a communicative situation. Research on these speech acts originated with Austin's (1962) observation that "in saying something we are doing something" (p. 12). His proposal of a three-way taxonomy of communicative acts includes: locutionary acts (saying something meaningful that can be understood), illocutionary acts (performing an act such as requesting or refusing), and perlocutionary acts (achieving something by saying something).

In 1976, Searle distinguished five (different) categories of speech acts:

(1) Representatives which commit the speaker to the truth of the expected proposition (i.e., asserting, concluding)

(2) Directives which are attempts by the speaker to get the addressee to do something (i.e., requesting, questioning)

(3) Commisives which commit the speaker to some future course of action (i.e., promising, threating, offering) 
(4) Expressives which express a psychological state ( i.e., thanking, apologizing, complimenting, welcoming)

(5) Declarations which tend to rely on extra _ linguistic institutions (i.e., christening, declaring war)

Searle proposes four types of felicity conditions for "requests" .Felicity conditions is a term widely used in speech act theory, first by Austin and later by Searle. In general felicity conditions are those of features of a context which have to be in a place in order for a speech act to be successful. These types of felicity conditions are: preparatory conditions, sincerity conditions, prepositional content conditions, future act of hearer), essential conditions (attempts to persuade the hearer to do the act). The speech act of requests uses the indirectness to attain the politeness level.

\section{Request}

One of the most frequently occurring of speech acts is request. Blum _ Kulka, House and Kasper (1989) did many numbers of their studies to pragmatics of the speech acts. They developed a process for analyzing discourse data, by data elicitation tests. Some researchers have studied the performance of requests by a specific cultural groups: Trosborg (1995) studied Danish learners of EFL. All of these researchers found evidence of negative transfer of L1 pragmatics, and these researchers claimed the need for explicit instruction in making English request and learning the request strategies (Appendix 1). Kahraman defines request expressions as "asking a hearer to do or quit doing something for a speaker or someone else who stands in relation to the speaker, hence the hearer will physically or psychologically have made efforts and the speaker will have gained benefits." Request is a speech act that has been investigated in inter language pragmatic research because of frequent occurrence in the target language community (Achiba, 2003).Early studies on requests are mostly contrastive, comparing learners first and second language which relates to cross _ cultural pragmatic (Kasper , 1998) . A seminal collection of studies on cross _cultural pragmatic by BlumKulka, House and Kasper (1989) is a good example. Contrastive pragmatic studies have provided valuable insights into learners' target language as positive and negative transfer from L1 to L2, and developmental problems that learners may face because of applying new linguistic code and socio cultural norms in the target language.

With growing interest in teachability of target pragmatic forms and classroom _ based research in inter language pragmatic, Kasper (2001) studies the effects of instruction on L2 learners' pragmatic development. Also, Alcon (2005) and Takahashi (2001) studied the effect of instruction on the development of pragmatic competence of L2 learners of English in making a request. The present review is also attempts to fill the effect of explicit and implicit instructions on Iranian lower intermediate learners' requestive strategies and their pragmatic competence. 


\section{Explicit Teaching Method}

House (1996) describes some systematic instruction concerning the use and function of routines provided orally; preparing some handouts consisting explicit meta pragmatic information, listening to tapes of their own language behavior. The most typical is Yoshimi's (2001) study in which procedures have five systematic and complete steps:

1) the explanatory handout: information about the function and use of the target items

2) the NS model: exposure to the native models of non- formal, extended discourse and the target items in such discourse.

3) the planning session: opportunities for planning the production of non- formal ,extended discourse.

4) communicative practice: opportunities for communicative practice of the target items in relation to extended discourse.

5) corrective feedback: feedback on the use of target items and the production of extended discourse (pp. 225-227).

Explicit learning refers to a conscious process in which learners are aware of the new knowledge they are receiving (Scmidt, 1995, 2001; Berry, 1994; Ellis, 1999). In addition, as Ellis (1994) mentioned, explicit learning involves the forming and testing of hypotheses in a search for the correct structure.

\section{Implicit Teaching Method}

In this method there is no presentation of information, there is more extensive conversational practice, providing students with some extended questions to discover the pragmatic patterns by themselves, the learners complete the tasks without the explicit instruction, short discussions, and feedback is teacher _ oriented. Takahashi (2001) classified implicit teaching in three conditions:

1) In the form _ comparison condition

2) In the form _ search condition

3) In the meaning _ focused condition (p.174)

Implicit learning is defined as a non- conscious process in which learners are not aware of what is being learned, since they only focus attention on the surface features of a complex stimulus domain. (1989; Winter and Reber, 1994). According to Ellis (1994) implicit learning is considered as the acquisition of knowledge about the underlying structure of a complex stimulus environment by a natural process without a conscious operations.

\subsection{The Comparative Studies of Explicit and Implicit Instruction}

Previous studies revealed that pragmatic competence can be taught via different teaching 
methods. Most of them choose the explicit versus implicit teaching. As a result, the explicit teaching method is more effective than implicit teaching method. House's (1996) explicit learners did better in discourse than implicit. House (1996) explored that more explicit instruction raised learners' awareness of pragmatic knowledge. Rose and $\mathrm{Ng}$ (2001) explained the results of a study that compares the inductive and deductive approach (the same as explicit \& implicit approaches) to the teaching of pragma linguistic competence (Leech, 1983; Thomas ,1987).

Regarding the differences between explicit and implicit learning with or without awareness (Schmidt, 2001; DeKeyser, 2003), there are two types instructions deriving from this distinction. As Doghty and Williams $(1998$, b) stated the teacher may considers these two types of instructions to have an easier teaching process for learners. On the other hand, explicit teaching involves directing the learners' attention to the target structure by discussing about them. On the other hand, an implicit teaching refers to attract the learners' attention to the target structure without any type of metalinguistic explanations. Safont's (2001) research identified the effects of the instruction to develop learners' ability to produce appropriate request. Safot (2001) first provided the learners with a list of request linguistics formulations which varied based on the level of the politeness. The students were exposed to a variety of indirect, conventionally indirect and direct forms for expressing request in English. After the explanations, the students were supposed to identify the same forms in some transcripts that involved semi-authentic situation. Then they practiced some activities and the students' answers were discussed by employing meta pragmatic explanations.

As the result, the important difference between explicit and implicit instruction is related to the provision or absence of rules. As Doughty (2003: 2650 mentions, in explicit instruction rules are explained to the learners, while in an implicit instruction there is no direct explanation to the rules to the learners.

\section{Conclusion}

The speech act of request is an important part of pragmatic competence that has led to research in the field of inter language pragmatics. Kahraman defines request expressions as "asking a hearer to do or quit doing something for a speaker or someone else who stands in relation to the speaker, hence the hearer will physically or psychologically have made efforts and the speaker will have gained benefits." Request is a speech act that has been investigated in inter language pragmatic research because of frequent occurrence in the target language community (Achiba, 2003). The purpose of the current paper was to review the effect of the instruction and primarily, the explicit and implicit instruction on learners' request strategies (Appendix 1). Applying the explicit and implicit instruction enhance the learners' pragmatic awareness. And it showed that when there is raising awareness in learners they can learn better to produce something pragmatically and explicit and implicit instruction helped the learners to distinguish the speech act of request at beginning.

Furthermore, some pedagogical implications can be drawn from the current review. Firstly, it 
seems that the distinguishing between the explicit and implicit language instruction is important for language pedagogy and the learners need further development their pragmatic competence in requesting. Secondly, In order to empower the learners to increase their pragmatic competence in relation to making requests, exposing the learners to the patterns of this feature of speech act is recommended. Finally, the explicit and implicit instructions as the facilitative way of developing pragmatic competence are also suggested.

\section{References}

Achiba, M. (2003). Learning to request in a second language: A study of child inter language pragmatics, Clevedon, UK : Multili.

Austin, J. (1962). How To Do Things With Words. Oxford: Oxford University Press.

Bardovi-Harlig, K. (2001). Evaluating the empirical evidence: Grounds for instruction in pragmatics. In Kasper, G., \& Rose, K. (Eds.), Pragmatics and language teaching (pp. 11-32). Cambridge: Cambridge University Press.

Bardovi-Harlige., \& Hartford, B. (1993). Learning the rules of academic talk: A longitiudinal study of pragmatic change. Studies in Second Language Acquisition, 15, 279-304.

Berry, C. D. (1994). Implicit and Explicit learning of complex tasks. Ellis (ed.), Implicit and Explicit Learning of Languages. Academic Press. pp. 147-164.

Billmayer, K. (1990). I really like your lifestyle. ESL learners learning how to compliment. Penn Working Papers in Educational linguistics, 6, 31-48.

Blum- Kulka, S., House, J., \& Kasper, G. (1989). Cross- cultural pragmatics: Requests and apologies. Nowood, NJ :Albex.

Blum-kulka, S., \& Olshtain, E. (1987). Requests and Apologies: A cross cultural study of speech acts, realizations patters. Applied Linguistic, 5, 196-213.

Bouton, L. F. (1994). Conversational implicaturein a second languagelearned slowly when not deliberately taught. Journal of pragmatics, 22, 157-167.

Chopman, S. (2011). Pragmatics. US. Palgrave Macmiilan.

Crystal, D. (1997). A dictionary of linguistics and phonetics (4th ed.). Cambridge, MA: Blackwell.

Ellis, R. (1992). Learning to communicate in the classroom: A study of two learners' requests. Studies in second language Acquisition, 14, 1-23.

Ellis, R. (1994). The study of the second language acquisition. Oxford. Oxford University Press.

Ellis, R. (1994). Learning a second through interaction. Studies in Billingualism. Vol. 17. Amesterdam/ Philadelphia: John Benjamins Publishing Company. 
Fukuya, Y., \& Clark, M. (1999). Input enhancement of mitigators. In L. Bouton (Ed.), Pragmatics and Language Learning, 10, 163-178. Urbana-Champaign: DEIL, University of Illinois, Urbana-Champaign.

House, J. (1996).Developing pragmatic fluency in English as a foreign language: Routines and metapragmatic awareness. Studies in Second Language Acquisition, 19, 225-252.

Kasper, G. (1998). Interlanguage pragmatics. In H. Byrnes (Ed.), learning foreign and second languages: Perspectives in research and scholarship (pp. 183-208). New York: The modern language association of America.

Kasper, G., \& Rose, K. (1999). Pragmatics in SLA. Annual review of applied linguistics, 19, 81-104.

Lakoff, R. (1973). The logic of politeness: or minding your p's and q's', In Claudia Corum, t. Cedric Smith -Stark and Ann Weiser (Eds.), papers from the Ninth Regional meeting of the Chicago Linguistic Society, Chicago Linguistics Society, 292-305.

Lakoff, G. (1970). Irrigularityin syntax. Holt, Rinehart and Winsta.

Leech, G. N. (1983). Principles of pragmatics. London: Longman.

Rose, K. R. (2000). An exploratory cross-sectional study of interlanguage pragmatic development. Studies in Second language Acquisition, 22, 27-67.

Rose, K. R., Ng Kwai-Fun, C. (2001). Inductive and deductive teaching of compliments and compliment responses. In Rose, K.R., Kasper, G. (Eds.), Pragmatics in Language Teaching. Cambridge University Press, Cambridge, pp. 145-170.

Safont, P. (2001). Meta-pragmatic Perspectives on L3 Acquisition. Analyzing Requests in the EAP context. Unpublished doctoral dissertation. Castellon: Universitate Jaume I.

Schmidt, R. (1993). Consciousness learning and inter language pragmatics. In G. Kasper, \& S. Blum- Kulka (Eds.), Inter language pragmatics. Oxford: Oxford University Press.

Schmidt, R. (1995). Consciousness and Foreign language Learning: A tutorial on the role of attention and awareness in learning. In R. Schmidt (ed.), Attention and awareness in foreign language learning (Tachnical Report, 9). Honolulu: University of Hawaii, Second Language Teaching and Curriculum Center. pp. 1-63.

Schmidt, R. (2001). Attention. In P. Robinson (ed.), Cognition and second language instruction. New York: Cambridge University Press. pp. 3-33.

Searle, John. (1969). Speech acts: An essay in philosophy of language pragmatic. Cambridge, England: Cambridge University.

Siegel, M. (1994). Looking east: learning Japanese as a second language in Japan and the interaction of race, gender and social context. Unpublished doctoral dissertation, University of California, Berkeley.

Siegel, M. (1996). The role of learner subjectivity in sociolinguistic competency: Western 
women learning Japanese. Applied Linguistics, 17, 356-382.

Takahashi, S. (2001). The role of input enhancement in developing pragmatic competence. In K.R. Rose, \& G. Kasper (Eds.), Pragmatics in language teaching (pp.171-200). Cambridge: Cambridge University Press.

Thomas, J. (1983). Cross-cultural pragmatic failure. Applied Linguistics, 4, 91-112.

Trosborg, A. (1995). Interlanguage Pragmatics: Requests, Complaints, and apologies. Berlin: Mouton DeGruyter. http://dx. doi.org/10.1515/9783110885286

Winter and Reber, A.S. (1994). Implicit learning and the acquisition of natural language. In N. Ellis (ed.), Implicit and explicit learning of languages. London: Academic Press. pp. 115-145.

Yoshimi, D. R. (2001). Explicit instruction and JFL learner's use of interactional discourse markers. In Rose, K. R., Kasper, G. (Eds.), Pragmatics in Language Teaching. Cambridge University Press, Cambridge, pp. 223-244.

\section{Appendix}

Appendix 1. Request Strategies

\begin{tabular}{|c|c|}
\hline Direct levels & Strategies \\
\hline \multirow[t]{4}{*}{$\begin{array}{l}\text { Level 1: } \\
\text { Direct Strategies (impositives) }\end{array}$} & $\begin{array}{l}\text { Mood directives i.e. Leave me alone./Clean } \\
\text { up the kitchen. }\end{array}$ \\
\hline & $\begin{array}{l}\text { Performative i.e. I am asking you to } \\
\text { move your car. }\end{array}$ \\
\hline & $\begin{array}{l}\text { Obligation Statement i.e. I have to/ must } \\
\text { ask you to clean up the kitchen right now. }\end{array}$ \\
\hline & $\begin{array}{l}\text { Want statement i.e. I'd like to borrow } \\
\text { your notes for a little while. }\end{array}$ \\
\hline \multirow[t]{2}{*}{$\begin{array}{l}\text { Level 2: } \\
\text { Conventionally indirect strategies }\end{array}$} & $\begin{array}{l}\text { Suggestory formula i.e. How about } \\
\text { cleaning up the kitchen? Why don't you get } \\
\text { lost? }\end{array}$ \\
\hline & $\begin{array}{l}\text { Query preparatory i.e. Can I borrow } \\
\text { your notes? / Could you possibly get your } \\
\text { assignment down this week? / I was } \\
\text { wondering if you could give me alittle..... }\end{array}$ \\
\hline \multirow[t]{2}{*}{$\begin{array}{l}\text { Level } 3 \text { : } \\
\text { Non- Conventionally indirect strategies }\end{array}$} & $\begin{array}{l}\text { Strong hint i.e. ( intent: getting a lift } \\
\text { home) } \\
\text { Will you be going home now? }\end{array}$ \\
\hline & $\begin{array}{l}\text { Mild hint i.e. (intent: getting hearer to } \\
\text { clean the kitchen) } \\
\text { You've been busy here, haven't you? }\end{array}$ \\
\hline
\end{tabular}




\section{Copyright Disclaimer}

Copyright for this article is retained by the author(s), with first publication rights granted to the journal.

This is an open-access article distributed under the terms and conditions of the Creative Commons Attribution license (http://creativecommons.org/licenses/by/3.0/). 